\title{
CORRELATION OF MOTHERS WITH HISTORY OF DIABETES MELLITUS AND INFANTS WITH ANTI-GAD65
}

\author{
Nanda Fadhilah Witris Salamy ${ }^{1,3}$, Gadis Meinar Sari ${ }^{2}$, Bambang Purwanto ${ }^{2}$, Sulistiawati ${ }^{2}$ \\ ${ }^{1}$ Medical Science Master Program, ${ }^{2}$ Department of Physiology, Faculty of Medicine, Universitas Airlangga, \\ ${ }^{3}$ Universitas Nahdlatul Ulama, Surabaya, Indonesia
}

\begin{abstract}
This study aimed to determine the relationship between mothers with history of diabetes mellitus with Infants with Anti-GAD65. This study was an observational analytic study with a cohort study design. The case studied was the relationship between maternal history of diabetes mellitus and infants with Anti-GAD65. This study was conducted at Jemursari Hospital in Surabaya. Sample examination was performed with a GAD65 autoimmune rapid test. Then, a statistical test was performed to determine its relationship with other variables. There was no relationship between mothers with history of diabetes mellitus and infants with Anti-GAD65, but there was a significant relationship between Anti-GDA65 Mothers with Infants with AntiGAD65. Thus, there was a possibility of transplacental antibody transfer and viral infections during pregnancy that cause damage to pancreatic beta cells. History of diabetes mellitus was not related to infants with Anti-GAD65, but there was a relationship between Anti-GAD65 Mothers with Anti-GAD65 BAyi so that there is a transfer of transplacenta antibodies and viral infections during pregnancy that can cause damage to beta pancreatic cells in infants.
\end{abstract}

Keywords: Diabetes mellitus; GAD65; transplacental antibodies; virus infection; pregnancy

\section{ABSTRAK}

Penelitian ini bertujuan untuk mengetahui hubungan riwayat ibu Diabetes Melitus dengan Anti-GAD65 Bayi. Penelitian ini merupakan penelitian observasional analitik dengan desain penelitian kohort. Kasus yang diteliti adalah hubungan riwayat ibu diabetes mellitus dengan anti-GAD65 bayi. Lokasi penelitian dilakukan di RSI Jemursari Surabaya. Pemeriksaan sampel dilakukan dengan rapid test autoimmune GAD65. Kemudian dilakukan uji statistik untuk mengetahui hubungannya dengan variable lainnya. Tidak terdapat hubungan antara riwayat Ibu Diabetes Melitus dengan Anti-GAD65 Bayi, namun terdapat hubungan bermakna antara Anti-GDA65 Ibu dengan Anti-GAD65 Bayi, sehingga ada kemungkinan terjadi transfer antibodi transplacental dan infeksi virus pada saat kehamilan yang menyebabkan kerusak sel beta pancreas. Riwayat Ibu Diabetes Melitus tidak berhubungan dengan Anti- GAD65 Bayi, namun terdapat Hubungan antara Anti-GAD65 Ibu dengan AntiGAD65 BAyi sehingga dimungkinkan terdapat transfer antibodi transplacenta dan infeksi virus pada saat kehamilan yang dapat menyebabkan kerusakan sel beta pancreas pada bayi.

Kata kunci: Diabetes melitus; GAD65; antibodi transplasenta; infeksi virus; kehamilan

Correspondence: Nanda Fadhilah Witris Salamy, Medical Science Master Program, Faculty of Medicine, Universitas Airlangga, Surabaya, Indonesia. E-mail: witrisalamy@gmail.com

pISSN:2355-8393 • eISSN: 2599-056x • doi: http://dx.doi.org/10.20473/fmi.v55i4.17329

- Fol Med Indones. 2019;55:301-305 • Received 8 Feb 2017• Accepted 24 Aug 2017

- Open access under CC-BY-NC-SA license • Available at https://e-journal.unair.ac.id/FMI/

\section{INTRODUCTION}

Various epidemiological studies have shown an increasing trend in the incidence and prevalence of type 2 diabetes mellitus in various parts of the world. The World Health Organization (WHO) predicts a significant increase in the number of people with diabetes in the coming years. For Indonesia, WHO predicts an increase in the number of patients from 8.4 million in 2000 to around 21.3 million in 2030 (Pranoto 2011).
According to the 2012 American Diabetes Association (ADA), diabetes mellitus is a group of metabolic diseases with characteristic hyperglycemia that occurs due to abnormal insulin secretion, insulin action or both. Meanwhile, according to WHO, it is said that diabetes mellitus is something that cannot be stated in one clear and concise answer but in general can be said as a collection of anatomic and chemical problems that are the result of a number of factors where absolute or 
relative insulin deficiency is obtained and impaired function insulin. (Pranoto 2011).

Diabetes mellitus is a metabolic disease that is influenced by various factors, both in the form of environmental risk factors and hereditary or hereditary factors. The most influential type 1 diabetes mellitus is hereditary factors. A study reported 20 chromosome regions associated with susceptibility to the incidence of type 1 diabetes mellitus in humans. The biggest contribution comes from several genes located in the major histocompatibility complex (MHC) complex on chromosome 6p21.3 (Pociot 2002).

In type 2 diabetes mellitus, these two risk factors influence each other and can be grouped into (1) irreversible risk factors, (2) risk factors that can be corrected, and (3) other risk factors associated with diabetes risk (Tedjapranata 2009). Family history of diabetes mellitus is a risk factor that cannot be changed. This was demonstrated in one study where the incidence of diabetes mellitus in children with both parents of diabetes mellitus had a greater prevalence (60-70\%) than in children with one parent suffering from type 2 diabetes mellitus. To explain this, a study was conducted Genetic mapping to identify genome variations is also done in type 2 diabetes mellitus (Ahlqvist 2011). But both studies have not been able to reveal the detailed mechanism of family history in diabetes mellitus.

The pathogenesis of type 1 diabetes mellitus is an autoimmune reaction to proteins in pancreatic beta cells that cause destruction of pancreatic beta cells and deficiency of insulin secretion that leads to metabolic disorders. Whereas the pathogenesis of type 2 diabetes mellitus is a combination of genetic factors associated with impaired insulin secretion, insulin resistance and environmental factors. The main pathophysiological mechanisms in type 2 diabetes mellitus are a decrease in the value of insulin secretion and an increase in insulin resistance (Ozougwu 2013).

Biochemical evidence through a marker of immune reaction due to damage to pancreatic beta cells can also be used as a confirmation of the diagnosis of type 2 diabetes mellitus. Pancreatic beta cell autoimmune markers used include Glutamic Acid Decarboxilase Antibodies (GAD). GAD is known to be a major antigen in pancreatic beta cells (Baekkeskov 1990) and is an enzyme that catalyzes the formation of inhibitory neurotransmitters from glutamic acid (GABA). GAD has 2 forms of isoforms, namely GAD65 and GAD67 (Erlander 2001). GAD65 isoform is widely expressed by pancreatic beta cells in humans while GAD67 isoform is not commonly found. Two cohort studies conducted in Europe with subjects in excess of 1000 type 2 diabetes mellitus patients showed an anti-GAD65 prevalence of $10 \%$ (Tuomi 1999). While research in North America with subjects less than 200 people shows a prevalence value of $16 \%$ (Juneja 2001). Damage to pancreatic beta cells ultimately releases GAD65 out of the pancreatic beta cells and into the bloodstream

Autoantibodies in pancreatic beta cells have preceded the clinical development of diabetes mellitus in humans and diabetic-induced animals (NOD). Pancreatic beta cell autoantibodies can be transferred through the placenta from maternal pancreatic beta cells that have positive antibodies to their children (Hamalainen et al 2000). The effect of pancreatic beta cell antibodies transmitted in offspring from the maternal line is still unknown. In a study conducted by Koczwara et al in 2014, it was shown that pancreatic beta cell antibodies in umbilical cord blood of type 1 diabetes mellitus correlate with the level of antibodies found in maternal blood at delivery, this shows the transmission of these antibodies through the placenta (Koczwara 2014). In addition to transmission pathways through the placenta, viral infections can also contribute to developing autoimmune reactions in pancreatic beta cells (Shulman 2014). However, in research conducted by Serreze, this viral infection does not initiate the formation of an autoimmune reaction in pancreatic beta cells but only accelerates the process of autoimmune reactions (Serreze 2000). Based on the above background, this study will analyze the relationship between the history of maternal diabetes mellitus with infant Anti-GAD65.

\section{MATERIALS AND METHODS}

The subjects were determined by the purposive sampling method. Then the subject was divided into 2 groups, exposed and unexposed groups. The selection of unexposed groups and exposed groups is adjusted according to the inclusion and exclusion criteria that have been determined based on the group selection flow. On the subject of research, intravenous blood specimens were taken to measure Random blood sugar and Anti-GAD65 examination. Sampling of specimens was carried out just prior to delivery. Shortly after the delivery process, the baby's cord blood specimen is collected. The specimen is then subjected to AntiGAD65 examination.

\section{RESULTS}

In this study 58 subjects were collected. Of the 58 subjects, there were 29 mothers with a family history of diabetes mellitus (exposed group) and 29 blood 
specimens of mother without a family history of diabetes mellitus (unexposed group). From 29 mother's blood specimens with a family history of diabetes mellitus, 3 positive baby blood specimens were obtained. While from 29 maternal blood specimens without a family history of diabetes mellitus, 1 positive baby's blood specimen was found with Anti-GAD65.

The highest number of subjects was at the age of 20-35 years, as many as 50 people $(86.2 \%)$ and the lowest was at the age above 35 years, as many as 8 people $(13.8 \%)$. In the exposed group aged 20-35 years there were 22 people $(75.9 \%)$ while in the unexposed group aged 2035 years there were 28 people $(96.6 \%)$. Statistical analysis showed that $\mathrm{p}=0.022(\mathrm{p}<0.05)$ and CI 1.019 77.905 which means that maternal age during pregnancy was related to a family history of diabetes mellitus in the mother.

Overall, the number of mothers with GDA results $=200$ was 45 people $(77.6 \%)$ from 58 study subjects. While mothers with GDA results $<200$ were 13 people $(22.4 \%)$. In the control group, the number of mothers with GDA results $<200$ was 2 people $(6.9 \%)$ while in the exposed group, the number of mothers with GDA results $<200$ was 11 people $(37.9 \%)$. Statistical analysis showed that $\mathrm{p}=0.005(\mathrm{p}<0.05)$ and CI 1,632 - 41,704 which means that the results of maternal GDA examination were related to a family history of diabetes mellitus in the mother.

From the research that has been done, the highest number of subjects is 50 people $(86.2 \%)$ with negative GAD mothers, while mothers with positive GAD are 8 people $(13.8 \%)$. While the highest GAD of positive mothers was found in the exposed group of 6 people $(20.7 \%)$ while in the control group it was found that the number of GAD of positive mothers was 2 people $(6.9 \%)$. Statistical analysis showed that $\mathrm{p}=0.128(\mathrm{p}>$ 0.05 ) and CI 0.647-19.166 which means that the results of maternal GAD examination were not related to family history of diabetes mellitus in the mother.

In this study, specimens were taken from cord blood after the baby was born. The results obtained as many as 4 subjects $(6.9 \%)$ who gave a positive GAD value and 54 subjects $(93.1 \%)$ who gave a negative GAD value. In the control group positive GAD was 1 subject $(3.4 \%)$ while negative GAD was 28 subjects $(97.6 \%)$. While in the exposed group there were 3 subjects $(10.3 \%)$ who gave a positive GAD value and 26 subjects (89.7\%) who gave a negative GAD value. Statistical analysis showed that $p=0.300(p>0.05)$ and CI $0.316-33.049$ which means that the results of Anti-GAD65 examination of infants are not related to a family history of diabetes mellitus in the mother.
In the exposed group, the number of study subjects who had Anti-GAD65 positive-value infants was as many as 6 people $(20.7 \%)$, in which there were 3 subjects with Anti-GAD65 positive mothers (50\%). Statistical analysis showed that $\mathrm{p}=0.000(\mathrm{p}<0.05)$ and CI $1.000-$ 3.999, which means that maternal Anti-GAD65 examination results were related to infants with AntiGAD65.

\section{DISCUSSION}

A 2001 study showed transplacental antibody transfer in children with mothers who have type 1 diabetes mellitus. The study used maternal blood specimens taken during the first trimester of pregnancy and during labor. In addition, this study also used a baby cord blood specimen shortly after delivery (Hamalainen 2000).

The results of this study indicated that there was no significant difference between the history of Maternal diabetes mellitus and Infants with Anti-GAD65. However, if viewed from the graph there was a tendency for positive values in the exposed group, be it positive values from the results of the Anti-GAD65 examination of the mother, the baby's Anti-GAD65 or the mother's random blood sugar. This tendency may be caused by an increase in blood glucose levels over a long period of time which can damage pancreatic beta cells (Ozougwu et al 2013). The progressive damage of pancreatic beta cells will be able to result in the release of the GAD enzyme which is a biomarker of pancreatic beta cell damage. Thus, it can be concluded that chronic hyperglycemia can cause the formation of Anti-GAD65 in the blood circulation of the subject (Mother).

GAD is known to be the main antigen in pancreatic beta cells (Baekkeskov 1990). GAD is an enzyme that catalyzes the formation of inhibitory neurotransmitters from glutamate acid/GABA (Erlander 2001). So that Glutamic Acid Decarboxilase Antibodies (GADs) can be used as an autoimmune marker of pancreatic beta cells (Glasser 1998, Clemons 1999). In a cross sectional study in 1995, it was found that in the group of adult patients diagnosed with diabetes mellitus showing progressive damage to pancreatic beta cell function during the 10 year follow-up period, $60-80 \%$ of these patients showed positive GAD 65 antibodies (Niskanen, et al 1995). The 2008 study stated that the clinical diagnosis of GAD 65 antibodies can be found in the span of years before the onset of diabetes mellitus and can be used to estimate patients' needs for insulin (Uibo, et al 2008). So the results of a positive anti-GAD65 examination can show progressive damage to pancreatic beta cells and can predict the incidence rate of diabetes mellitus. 
From this research, there was a tendency for the relationship between Anti-GAD65 in maternal and infant blood circulation. This can be caused by the transfer of transplacental anti-GAD65 antibodies from the mother to her baby. Several studies have been carried out, including by Kochwaran in 2004. From these studies it was found that antibodies from pancreatic beta cells (Insulin Antibodies and Glutamate Acid Decarboxylase) in umbilical cord blood of infants with maternal diabetes mellitus are related to levels of antibodies found in maternal blood at the time of labor process, this study also suggests that there is a possibility of antibody transfer through the placenta (Kochwara 2004).

It is known that during the second trimester of pregnancy, maternal immunoglobulin is actively transported across the placenta to the fetus. Antibody transport is faster during the last trimester until delivery, and the concentration of $\mathrm{IgG}$ in the fetus exceeds the concentration of $\mathrm{IgG}$ in the mother. Either maternal IgA or IgM are transferred to kejanin. In this study it was detected that GAD65A and IA-2A were mostly from IgG subclasses as Sephrose Protein A was used to separate free from autoantigen labels. From the study of bound antibody vaccination studies 26 it was known that a baby's ability to produce an $\mathrm{IgG}$ response increased over the first year, but the adult response to antigenic protein is not reached until 12 to 24 months. We assume that we have measured GAD65A and IA-2A transferred from mother to child. It is therefore possible that subclinical islet autoimmunity in pregnant women may explain the increased risk for type 1 diabetes in offspring (Kochwara 2004).

In addition to this theory, autoimmune reactions on pancreatic beta cells are influenced by various factors, both genetic and environmental factors (Leiter 1998). Coxsackie virus infection can also contribute to developing an autoimmune reaction in pancreatic beta cells (Coppieters 2014). However, in research conducted by Serreze, this viral infection does not initiate the formation of an autoimmune reaction in pancreatic beta cells but only accelerates the process of autoimmune reactions. So the time of occurrence of infection is very important to know (Serreze 2000).

The accelerated development of diabetes mediated by the virus can occur because of three different but not binding mechanisms, including direct pancreatic infection, molecular mimicry on $\mathrm{T}$ cells and bystander activation (Coppieters 2014). In the absence of direct infection and lysis of pancreatic beta cells, pancreatic and molecular mimicry infections will cause T-cell activation through antigen presentation in the main histocompatibility complex (MHC).

However, bystander activation will involve activation of polyclonal lymphocytes by cytokines that secrete antigen presenting cells (APC). Thus, bystander activation is not a specific antigen, and depends on the presence of autoreactive $\mathrm{B}$ and $\mathrm{T}$ cells. host cells targeted by the virus and the time of occurrence of infection that affects the level of autoimmunity in pancreatic beta cells is highly dependent on the possibility of bystander activation (Pane 2014).

\section{CONCLUSION}

There is no relationship between the history of Maternal diabetes mellitus and Infants with Anti-GAD65, but there is a significant relationship between Anti-GDA65 Mothers with Infants with Anti-GAD65, so there is a possibility of transplacental antibody transfer, and viral infections during pregnancy that cause damage to pancreatic beta cells. Need further research in experimental animals with a history of the mother made to contain in the condition of diabetes mellitus and examined Anti-GAD65 parent and offspring. Need further research to find out the process and mechanism of transfer of antibodies from the mother of diabetes mellitus to the baby's blood circulation and how long it stays in the baby's blood. Anti-GAD65 examination of blood samples from mother and baby can be done, even though KIT still needs to be developed KIT which results are more sensitive and accurate.

\section{REFERENCES}

Ahlqvist E, Ahluwalia TS, Groop L (2011). Genetics of type 2 diabetes. Clinical Chemistry 57, 241-254

American Diabetes Association (2012). Diagnosis and classification of diabetes mellitus. Diabetes Care 35, 64-71

American Diabetes Association (2013). Standards of medical care in diabetes 2013. Diabetes Care 36, 1166

Baekkeskov S, Aanstoot H-J, Christgau S, Reetz A, Solimena M, Cascalhom, Folli F, Ritcher Olesen H, De Camilli P (1990). Identification of the 64K autoantigen in insulin-diabetes as the GABAsynthesizing enzyme glutamic acid decarboxylase. Nature (Lond) 347, =151-56

Banatvala JE, Bryant J, Schernthaner G, Borkenstein M, Schober E, Brown D, De Silva LM, Menser MA, Silink M (1985). Coxsackie B, mumps, rubella, and cytomegalovirus specific IgM responses in patients with juvenileonset insulin-dependent diabetes mellitus in Britain, Austria, and Australia. Lancet 1, 1409-1412 
Clements GB, Galbraith DN, Taylor KW (1995). Coxsackie B virus infection and onset of childhood diabetes. Lancet 346, 221-223

Coppieters KT, Wiberg A, von Herrath MG (2012). Viral infections and molecular mimicry in type 1 diabetes. APMIS 120, 941-949

Coppieters KT, Dotta F, Amirian N, Campbell PD, Kay TW, Atkinson MA, ,Roep BO, Von Herrath MG (2012). Demonstration of islet- autoreactive CD8 T cells ininsulitic lesions from recent onset and longterm type 1 diabetes patients. The Journal of Experimental Medicine 209, 51-60

Erlander MGNJK. Tillakaratne S. Feldblum N, et al (1991). Two genes encode distinct glutamate decarboxylases with different responses to pyridoxal phosphate. Neuron 7, 91-100

Fujinamia RS, Von Herrath MG, Christen URS, Whitton JL (2006). Molecular mimicry, bystander activation, or viral persistence infections and autoimmune disease. Clinical Microbiology Review, 80-94

Hamalainen AM, Ronkainen MS, Akerblom HK, Knip M (2000). Postnatal elimination of transplacentally acquired disease-associated antibodies in infants born to families with type 1 diabetes: the Finnish TRIGR Study Group: Trial to Reduce IDDM in the Genetically at Risk. J Clin Endocrinol Metab 85, 4249-4253

Juneja R, Hirsch IB, Naik RG, et al (2001). Islet cell antibodies and glutamic acid decarboxylase antibodies, but not the clinical phenotype, help to identify type $1(1 / 2)$ diabetes in patients presenting with type 2 diabetes. Metabolism 50, 1008-1013

Koczwara KE, Bonifacio, Ziegler AG (2004). Transmission of maternal islet antibodies and risk of autoimmune diabetes in offspring of mothers with type 1 diabetes. Diabetes 53, 1-4

Leiser R, Kaufmann P (1994). Placental structure: In a comparative aspect. experimental and clinical endocrinology, 102, 122-134. http://dx.doi.org/10.1055/s0029-1211275
Newsholme P, Keane K, et al (2013). The impact of inflammation on pancreatic $\beta$-cell metabolism, function and failure in T1DM and T2DM: Commonalities and differences. Intech

Ozougwu KC, Obimba CD, Belonwu CB, Unakalamba (2013). The pathogenesis and pathophysiology of type 1 and type 2 diabetes melitus J. Physiol. Pathophysiol 4, 46-57

Pociot F, McDermott MF (2002). Genetics of type 1 diabetes mellitus (Review). Genes Immun 3, 235-249

Pranoto A, Sutjahjo A, Tjokroprawiro A, Murtiwi S, Wibisono S (2011). Konsensus pengelolaan dan pencegahan diabetes melitus tipe 2 di Indonesia 2011. LPPM , Universitas Airlangga, Surabaya

Serreze DV, Ottendorfer EW, Ellis TM, Gauntt CJ, Atkinson MA (2000). Acceleration of type 1 diabetes by a coxsackievirus infection requires a preexisting critical mass of autoreactive T-cells in pancreatic islets. Diabetes 49, 708-711

Shulman LM, Hampe CS, Ben- Haroush A, et al (2014). Antibodies to islet cell autoantigens, rotaviruses and/or enteroviruses in cord blood and healthy mothers in relation to the 2010-2011 winter viral seasons in Israel: a pilot study Diabet Med 31, 681685

Tedjapranata M (2009). Diabetes di usia lanjut memang berbahaya, namun dapat dijinakkan. Available at: http://www.gbimawarsaron.com/kesehatan/27-diabetes- mellitus. Accesed March 12, 2016

Tuomi T, Carlsson $\AA$, Li H, Isomaa A, Miettinen A, Nissén M, Ehrnström B-J, Forsén B, Snickars B, Lahti K, Forsblom C, Saloranta C, Taskinen M-R, Groop LC (1999). Clinical and genetic characteristics of type 2 diabetes with and without GAD antibodies. Diabetes 48, 150-157

Uibo R, Lernmark A (2008). GAD65 autoimmunityclinical studies. Adv Immunol 100, 39-78

WHO 1999. Definition, diagnosis and classification of diabetes mellitus and its complications, report of a WHO Consultation World Health Organization, Department of Non communicable Disease Surveillance, Geneva 